\title{
Health of the black immigrant population during the COVID-19 pandemic: a scoping
} review

\author{
Saúde da população imigrante negra durante a pandemia de COVID-19: uma revisão de escopo \\ Salud de la población inmigrante negra durante la pandemia del COVID-19: una revisión de
}

alcance

Received: 11/29/2021 | Reviewed: 12/07/2021 | Accept: 12/20/2021| Published: 01/01/2022

\author{
Flaviane Andreele Jacinto Da Silva \\ ORCID: https://orcid.org/0000-0002-2126-5169 \\ Universidade Federal do Paraná, Brazil \\ E-mail: fla.andreele@gmail.com \\ Aida Maris Peres \\ ORCID: https://orcid.org/0000-0003-2913-2851 \\ Universidade Federal do Paraná, Brazil \\ E-mail: aidamaris.peres@gmail.com \\ Rafaela Gessner Lourenço \\ ORCID: https://orcid.org/0000-0002-3855-0003 \\ Universidade Federal do Paraná, Brazil \\ Email: rafaelagessner@ufpr.br
}

\begin{abstract}
The black population has had a distinct impact on incidence and lethality during the COVID-19 pandemic. On immigrants, there are gaps in their health reality, few countries identify the nationality of the infected population or those who died because of COVID-19 in the notification forms. The aim of this research is to identify the health situation of black immigrants in the world during the COVID-19 pandemic. The method chosen was a scoping review, with the formulation of a research question that sought information about the health situation of black immigrants during the COVID-19 pandemic. Primarily 807 documents were founded, among them, there were petitions, books, manuals, reports, editorials, letters to the editor, and articles. After applying the inclusion and exclusion criteria, as well as removing repeated files, 13 materials remained to compose the final sample of this review, including articles, letters to the editor, editorial, and commentary. The data point to silence from the academic community and a lack of in-depth debates on how structural racism is decisive in the health of the black population, as well as material that discussed the health of the immigrant population in general.
\end{abstract}

Keywords: Emigrants and immigrants; COVID-19; Racism; Global Health.

\section{Resumo}

A população negra tem sofrido impacto distinto na incidência e letalidade durante a pandemia da COVID-19. A respeito dos imigrantes, existem lacunas sobre sua realidade de saúde, pois poucos países identificam a nacionalidade da população infectada ou que faleceu em decorrência da COVID-19 nas fichas de notificação do agravo. O objetivo desta pesquisa é identificar a situação de saúde dos imigrantes negros no mundo durante a pandemia da COVID-19. O método escolhido foi uma scoping review, com formulação da pergunta de pesquisa que buscasse informações sobre a situação de saúde dos imigrantes negros durante a pandemia da COVID-19. Primariamente foram encontrados 807 documentos, dentre eles havia petições, livros, manuais, relatórios, editoriais, carta ao editor e artigos. Após a aplicação dos critérios de inclusão e exclusão, assim como a retirada de arquivos repetidos, restaram 13 materiais para compor a amostra final desta revisão, dentre eles artigos, carta ao editor, editorial e comentário. Os dados apontam um silêncio da comunidade acadêmica e falta de debates aprofundados sobre como o racismo estrutural é decisivo na saúde da população negra, assim como material que discutisse a saúde da população imigrante no geral.

Palavras-chave: Emigrantes e imigrantes; COVID-19; Racismo; Saúde Global.

\section{Resumen}

La población negra ha tenido un impacto distinto en la incidencia y la letalidad durante la pandemia de COVID-19. Sobre los inmigrantes, existen vacíos en su realidad de salud, ya que pocos países identifican la nacionalidad de la población infectada o fallecida por COVID-19 en los formularios de notificación. El objetivo de esta investigación es identificar la situación de salud de los inmigrantes negros en el mundo durante la pandemia de COVID-19. El método 
elegido fue una revisión de alcance, con la formulación de una pregunta de investigación que buscaba información sobre la situación de salud de los inmigrantes negros durante la pandemia de COVID-19. En primer lugar, se encontraron 807 documentos, entre ellos, peticiones, libros, manuales, informes, editoriales, cartas al editor y artículos. Luego de aplicar los criterios de inclusión y exclusión, además de remover archivos repetidos, quedaron 13 materiales para componer la muestra final de esta revisión, incluyendo artículos, cartas al editor, editorial y comentarios. Los datos apuntan al silencio de la comunidad académica y la falta de debates en profundidad sobre cómo el racismo estructural es determinante en la salud de la población negra, así como en el material que discutió la salud de la población inmigrante en general.

Palabras clave: Emigrantes e inmigrantes; COVID-19; Racismo; Salud Global.

\section{Introduction}

Community transmission of the new coronavirus SARS-Cov-2, the etiologic agent of COVID-19, hit the world in the year 2020. The disease was elevated to a worldwide pandemic degree in March by the World Health Organization (WHO) and until August 7, 2021, 200, 840,180 cases and 4,265,903 deaths were confirmed throughout the world (WHO, 2021). In countries with a historical process embedded in the slave system, the disease took on a racial character; the largest numbers of both contaminated and dead people were members of the black population (Goes, et al., 2020). Despite this, there are gaps with regard to the records on how COVID-19 reached the black immigrant population in the world.

Almeida (2019) says that slavery was one of the facts in our Western society that mutilated civilizations and was one of the greatest genocides of culture and of people, leaving marks on the black population that extend to present days, people whose conditions of ascension have been denied. Racial prejudice is systematic as logic of action in conscious or unconscious practices and results in disadvantages or privileges, depending on which racial group the subjects belong to.

With the COVID-19 pandemic, the inequities in the world became more evident. The first data on the disease showed that the population that was responsible for its spread was, for the most part, the part of the population that has the privilege of world travel, with a fixed address for return. (Goes et al., 2020). Currently, data show that the population that is suffering the most from the impact caused by the disease, both incidence, and lethality, is the population with the least financial resources and the black population (Aldridge, et al., 2020).

The report produced by the Intensive Care National Audit and Research Centre (ICNARC) in England, pointed out that black people are present among critically ill patients, and have the highest chances of dying from COVID-19. The report points out that the population identified as BAME (Black, Asian, and minority ethnic), account for $64 \%$ of deaths and $95 \%$ in medical care $^{4}$. Another report in England points out that black people score 7.3 times more than any other population with racial cut of confirmed cases of COVID-19 (Razaq, et al., 2020).

In the United States, the country with the highest rate of confirmed cases, the COVID Racial Data Tracker was created, as a result of the partnership between the organized civil community, the non-governmental organization The Atlanta and the Boston University Center for anti-racist research, which pointed out that in the country the black population is dying 2.5 times more than the white population, in which the race is recognized and filled out on the forms. Almost one in three black Americans personally knows someone who died of COVID-19 (The COVID Racial Data Tracker, 2020).

In Brazil, the third country in the world with the highest number of confirmed cases, by July 2020, more than half of the black population hospitalized with a diagnosis of COVID-19 died, as 54.8\% of the black people who came to be hospitalized died, while in the hospitalized white population, the recorded lethality was $37.9 \%$. These data, released by the Ministry of Health (Prado, et al.,2020), point to structural racism, which permeates the reality of the black population, pointing out how this structure becomes determinant the influence of health. 
Research, Society and Development, v. 11, n. 1, e2511124073, 2021

(CC BY 4.0) | ISSN 2525-3409 | DOI: http://dx.doi.org/10.33448/rsd-v11i1.24073

There is no research that address the reality of black immigrants because the data end up mixing with the numbers of the black population. There is a need for studies that guide a perspective on the health reality of the immigrant population and the conditions under which the movement between territories, just as there are few countries that seek to identify in notification documents about the nationality of the infected population or who died because of COVID-19.

The aim of this research is to identify the health situation of black immigrants in the world during the COVID-19 pandemic, based on scientific publications. Its relevance is justified since studies that address the health of the black immigrant population are scarce.

\section{Methodology}

This is a scoping review undertaken based on the recommendations of the Joanna Briggs Institute (JBI) Reviewers Manual (Tricco, et al., 2018), following the International guide PRISMA-ScR (JBI, 2015), in the method proposed by the Joanna Briggs Institute, Reviewers Manual. This type of review follows the following steps: 1) identification of the research question; 2) identification of relevant studies; 3) selection of studies; 4) data analysis; and, 5) data grouping, synthesis and presentation (Peters, et al., 2017; Tricco, et al., 2016).

To formulate the research question, the strategy used was Participants, Concept and Context (PCC) (JBI, 2015), P (participants) - Black immigrants, C (concept) COVID-19/Epidemiological impact of COVID-19 and C (context) - pandemic of the COVID-19 world. The research question asked was: "What are the epidemiological relationships on the health of the black immigrant population during the COVID-19 pandemic?

The search strategy developed in the Portuguese language was: ("COVID-19" or "Coronavirus Infections") AND ("Epidemiology" or "Prevalence" or "Morbidity" or "Mortality") AND ("Emigrants and Immigrants") and in the English language: (“COVID-19” OR “Coronavirus Infections”) AND (“Epidemiology” or "Prevalence” OR "Morbidity" OR "Mortality") AND Emigrants and Immigrants. The strategy was adapted according to the specificity of each database used with a similar combination of descriptors. To find the maximum number of publications on the subject, the descriptor that pointed directly to the black immigrant population was not used, as this information could be presented in studies that studied the situation of the general immigrant population.

The inclusion criteria were the selection of complete material, from editorials, scientific communication articles, letters, essays, narratives of all kinds, available online, that addressed the health of the immigrant population outside their countries of origin during the COVID-19 pandemic, in Portuguese, Spanish and/or English, from January 2020 to September 25, 2020 and actualized in August of 2021.

Manuals were excluded from the search due to the length of these documents, as well as material that did not address the health of the black immigrant population.

The search took place throughout July 2020 and actualized in August 2021, and databases and two gray reading repositories were selected.

The selected databases were Web of Science, Cochrane, National Library of Medicine and National Institutes of Health (PubMed), Scopus. As the Scoping Review allows the use of gray literature data, Google Scholar was selected in search of a wider range of material to better achieve the objective proposed by the research question.

For the best visualization and organization of the content, authors made use of the Mendeley application, which organized and identified duplicate texts. Data were extracted to a spreadsheet in the Excel software for organization and 
visualization of the texts found. The information in this spreadsheet was fed and checked by the authors participating in the research.

\section{Results}

Primarily, 807 documents were found, including petitions, books, manuals, reports, editorials, letters to the editor, and articles. Subsequently, duplicated material was excluded from the databases, and 748 remained. After applying the inclusion and exclusion criteria, 195 remained. Then, the exclusion criterion for material that was not in Portuguese, English and Spanish was applied, and content in Italian (1), Ukrainian (2), German (1), French (1), Czech (1) was excluded.

The flow of inclusion of articles after the application of inclusion and exclusion criteria is shown in Figure 1.

Figure 1. Flow related to the selection process of the Scoping Review studies, adapted from PRISMA-ScR. Curitiba, Paraná, Brazil, 2021.

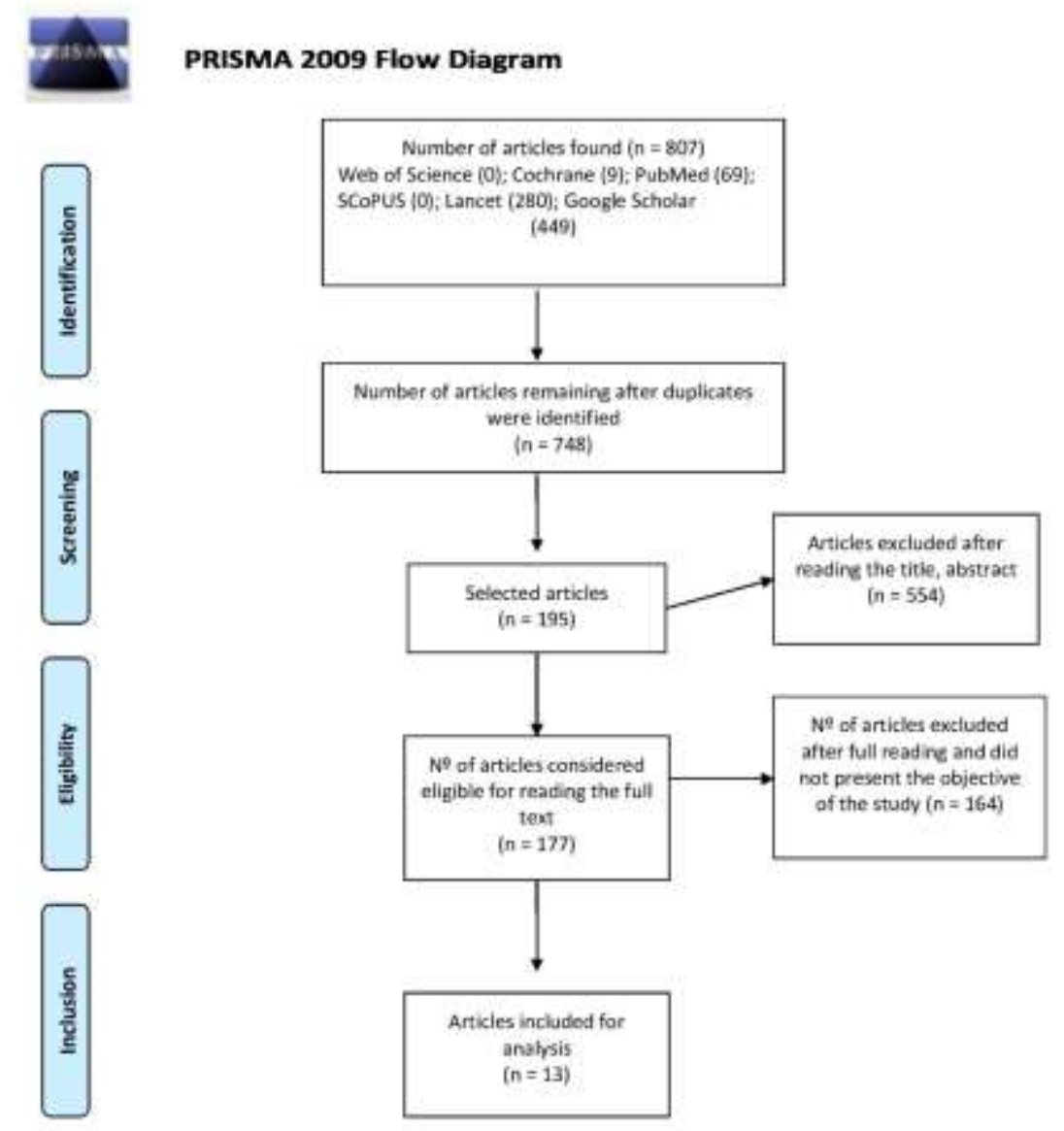

Source: Authors.

The articles that made up the sample of this study are shown in Table1. 
Research, Society and Development, v. 11, n. 1, e2511124073, 2021

(CC BY 4.0) | ISSN 2525-3409 | DOI: http://dx.doi.org/10.33448/rsd-v11i1.24073

Table 1 - Presentation of articles by author, type of material, journal, country of origin, objective and conclusion of the study.

\begin{tabular}{|c|c|c|c|c|c|c|}
\hline $\mathbf{N}$ & Authors & Type of Material & Magazine & $\begin{array}{c}\text { Country of data } \\
\text { analysis }\end{array}$ & The objective of the Study & Conclusion \\
\hline 1 & Krouse, H. J. & Letter to the Editor & $\begin{array}{l}\text { American Academy } \\
\text { of Otolaryngology - } \\
\text { Head and Neck } \\
\text { Surgery Foundation }\end{array}$ & $\begin{array}{l}\text { The United States of } \\
\text { América }\end{array}$ & $\begin{array}{l}\text { To show how COVID-19 } \\
\text { highlighted inequality in access } \\
\text { to health and exposure of } \\
\text { minority groups to the pandemic } \\
\text { and its social consequences } \\
\text { related to the health of this } \\
\text { population. }\end{array}$ & $\begin{array}{l}\text { After the pandemic, communities will } \\
\text { need to be strengthened through social } \\
\text { movements, changes in the economy, } \\
\text { political decisions, so that minority groups } \\
\text { can improve their health and reduce } \\
\text { inequality in terms of access to medical } \\
\text { care and the health of people in these } \\
\text { groups. }\end{array}$ \\
\hline 2 & Watson, et al. & Original reflection article & $\begin{array}{l}\text { Family Process - } \\
\text { Wiley Online Library }\end{array}$ & $\begin{array}{l}\text { The United States of } \\
\text { America }\end{array}$ & $\begin{array}{l}\text { To analyze the racial } \\
\text { inequalities of North } \\
\text { Americans, mainly black } \\
\text { people, immigrants, and other } \\
\text { non-white people, and how } \\
\text { COVID-19 showed access to } \\
\text { the economy of these groups, } \\
\text { worsening their mental health } \\
\text { situation. }\end{array}$ & $\begin{array}{l}\text { In addition to the aggravation of mental } \\
\text { problems that exist and the lack of access } \\
\text { to many treatments, the text leaves the } \\
\text { reflection on how the individual and } \\
\text { collective mental health of these minority } \\
\text { groups are aggravated by the racist and } \\
\text { economic structure, denying them access } \\
\text { to therapies and treatments in this } \\
\text { pandemic. }\end{array}$ \\
\hline 3 & Kapilashrami, et al. & Editorial & $\begin{array}{l}\text { The British Journal } \\
\text { of Psychiatry }\end{array}$ & England & $\begin{array}{l}\text { This editorial establishes } \\
\text { what can be behind these two } \\
\text { phenomena (COVID-19 and } \\
\text { Racism), explaining how } \\
\text { social structures and } \\
\text { disadvantages caused by racism } \\
\text { can increase } \\
\text { inequalities in times of crisis. }\end{array}$ & $\begin{array}{l}\text { The virus is not racist, but our social } \\
\text { structures and reactions to the crisis reflect } \\
\text { values and structures of power that } \\
\text { continue to discriminate and determine } \\
\text { worse outcomes for some more than for } \\
\text { others. }\end{array}$ \\
\hline
\end{tabular}


Research, Society and Development, v. 11, n. 1, e2511124073, 2021

(CC BY 4.0) | ISSN 2525-3409 | DOI: http://dx.doi.org/10.33448/rsd-v11i1.24073

\begin{tabular}{|c|c|c|c|c|c|c|}
\hline 4 & Shadmi, E., et al. & $\begin{array}{l}\text { Original reflection article } \\
\text { (Qualitative) }\end{array}$ & $\begin{array}{l}\text { International Journal } \\
\text { for Equity in Health }\end{array}$ & Worldwide data & $\begin{array}{l}\text { Compilation of data from } 13 \\
\text { countries that included case } \\
\text { studies from various regions of } \\
\text { the world: China, Brazil, } \\
\text { Thailand, Sub-Saharan Africa, } \\
\text { Nicaragua, Armenia, India, } \\
\text { Guatemala, United States of } \\
\text { America, Israel, Australia, } \\
\text { Colombia, and Belgium. }\end{array}$ & $\begin{array}{l}\text { It encourages researchers to continue to } \\
\text { advance global knowledge about issues } \\
\text { related to equity in health at COVID-19, } \\
\text { through rigorous research and generation } \\
\text { of a strong evidence base of new empirical } \\
\text { studies in this field, especially the } \\
\text { alarming data given to the deaths of the } \\
\text { black population. }\end{array}$ \\
\hline 5 & Glover, et al. & $\begin{array}{l}\text { Database review article / } \\
\text { Quantitative }\end{array}$ & $\begin{array}{l}\text { Journal of Clinical } \\
\text { Epidemiology }\end{array}$ & $\begin{array}{l}\text { Database } \\
\text { article }\end{array}$ & $\begin{array}{l}\text { Literature-based review article } \\
\text { to identify and categorize the } \\
\text { adverse effects of COVID-19 on } \\
\text { lockdown measures. }\end{array}$ & $\begin{array}{l}\text { Political interventions concerning } \\
\text { COVID-19 can generate or exacerbate } \\
\text { interactive and multiplicative property } \\
\text { damage, the BAME* population ends up } \\
\text { suffering more in this period of lockdown, } \\
\text { whether due to mental health, restricted } \\
\text { access to basic services, and working } \\
\text { conditions. }\end{array}$ \\
\hline 6 & Treweek, et al. & Comment & The Lancet & $\begin{array}{l}\text { World Data - } \\
\text { Organized by Oxford } \\
\text { Center for Evidence- } \\
\text { Based Medicine }\end{array}$ & $\begin{array}{l}\text { Reflection on world data and } \\
\text { how it affects the population } \\
\text { labeled as BAME*. }\end{array}$ & $\begin{array}{l}\text { BAME individuals - generally over- } \\
\text { represented of the disease - must be an } \\
\text { integral part of the social effort in search } \\
\text { of equity practices, especially the black } \\
\text { population. } \\
\text { The omission has consequences, like } \\
\text { people losing their lives for these } \\
\text { inequalities. }\end{array}$ \\
\hline 7 & Desai, \& Samari. & Original reflection article & $\begin{array}{ll}\text { Perspect } & \text { Sex } \\
\text { Reprod Health }\end{array}$ & $\begin{array}{l}\text { The United States of } \\
\text { América }\end{array}$ & $\begin{array}{l}\text { To discuss the immigrants' } \\
\text { access to "sexual and } \\
\text { reproductive health services" } \\
\text { during the COVID-19 } \\
\text { pandemic, and how immigrants' } \\
\text { exclusion affects ways of }\end{array}$ & $\begin{array}{l}\text { The solutions presented concerning } \\
\text { public health services must present } \\
\text { clinical services linked to COVID-19, } \\
\text { surveillance and evaluation research } \\
\text { programs, policies that address the health } \\
\text { and needs of immigrants. In addition to }\end{array}$ \\
\hline
\end{tabular}


Research, Society and Development, v. 11, n. 1, e2511124073, 2021

(CC BY 4.0) | ISSN 2525-3409 | DOI: http://dx.doi.org/10.33448/rsd-v11i1.24073

\begin{tabular}{|c|c|c|c|c|c|c|}
\hline & & & & & $\begin{array}{l}\text { dealing with the pandemic by } \\
\text { showing that it is an important } \\
\text { key in fighting the virus and } \\
\text { including immigrants within } \\
\text { health and society programs. }\end{array}$ & $\begin{array}{l}\text { resources that should be directed to this } \\
\text { program "Reproductive and sexual health } \\
\text { services". Political inclusion methods } \\
\text { recognize immigrants as part of the } \\
\text { population. }\end{array}$ \\
\hline 8 & Guijarro, et al. & Quantitative Article & medRxiv & Spain & $\begin{array}{l}\text { To assess the incidence of } \\
\text { COVID-19 among migrants } \\
\text { from different areas compared } \\
\text { to the Spaniards living in } \\
\text { Alcorcón. }\end{array}$ & $\begin{array}{l}\text { There was a marked increase in the risk } \\
\text { of COVID-19 among migrants from } \\
\text { Saharan Africa, the Caribbean, and Latin } \\
\text { America residing in Spain. Reasons } \\
\text { behind this increased risk and social and } \\
\text { health implications deserve more } \\
\text { attention. }\end{array}$ \\
\hline 8 & Bojorquez, et al. & Quantitative Article & medRxiv & Mexico & $\begin{array}{l}\text { To describe the epidemiology } \\
\text { of suspected cases of COVID- } \\
19 \text { in transit migrants and } \\
\text { asylum seekers in Mexico and } \\
\text { compare the characteristics of } \\
\text { the non-migrant population. }\end{array}$ & $\begin{array}{l}\text { Migrants and asylum seekers in Mexico } \\
\text { are at increased risk for infectious } \\
\text { respiratory diseases and may be } \\
\text { disproportionately affected by COVID- } \\
19 .\end{array}$ \\
\hline 10 & Aldridge, et al. & Quantitative Article & $\begin{array}{l}\text { Wellcome Open } \\
\text { Research }\end{array}$ & England & $\begin{array}{l}\text { To examine the risk of death by } \\
\text { COVID-19, with a comparison } \\
\text { between the BAME groups, } \\
\text { seeking to explain the regional } \\
\text { differences in the ethnic } \\
\text { composition of the population. }\end{array}$ & $\begin{array}{l}\text { The analysis adds to the evidence that } \\
\text { BAME people are at a higher risk of } \\
\text { death from COVID-19, even after } \\
\text { adjusting for the geographic region, but } \\
\text { was limited by the lack of data on deaths } \\
\text { outside } \\
\text { NHS (National Health Service) settings } \\
\text { and ethnicity. }\end{array}$ \\
\hline 11 & Lassale, et al. & Quantitative Article & $\begin{array}{lr}\text { Elsevier } & \text { (Brain, } \\
\text { Behavior, } & \text { and }\end{array}$ & England & $\begin{array}{l}\text { To examine the role of } \\
\text { socioeconomic, mental health }\end{array}$ & $\begin{array}{l}\text { There were ethnic differences in the risk } \\
\text { of hospitalization by COVID-19 and }\end{array}$ \\
\hline
\end{tabular}


Research, Society and Development, v. 11, n. 1, e2511124073, 2021

(CC BY 4.0) | ISSN 2525-3409 | DOI: http://dx.doi.org/10.33448/rsd-v11i1.24073

\begin{tabular}{|c|c|c|c|c|c|c|}
\hline & & & Immunity) & & $\begin{array}{l}\text { and pro-inflammatory factors in } \\
\text { a community sample. }\end{array}$ & $\begin{array}{l}\text { these do not seem to be fully explained by } \\
\text { measured factors. If replicated, results } \\
\text { have implications for health policy, } \\
\text { including targeting prevention advice and } \\
\text { vaccination coverage. }\end{array}$ \\
\hline 12 & Rose, et al. & Quantitative Article & medRxiv & England & $\begin{array}{l}\text { This is a cross-sectional } \\
\text { ecological analysis of England's } \\
\text { top-level local authorities, } \\
\text { looking to investigate the } \\
\text { relationship between high } \\
\text { mortality rates and minorities. }\end{array}$ & $\begin{array}{l}\text { This study provides evidence that both } \\
\text { income deprivation and ethnicity are } \\
\text { associated with higher mortality from } \\
\text { COVID-19. }\end{array}$ \\
\hline 13 & McBride, et al. & Original quantitative article & PsyArXiv & $\begin{array}{l}\text { Data from several } \\
\text { countries. }\end{array}$ & $\begin{array}{l}\text { To monitor the mental impacts } \\
\text { of the COVID- } 19 \text { pandemic in } \\
\text { patients who have suffered } \\
\text { severe respiratory symptoms, } \\
\text { apply the C19PRC + test, in } \\
\text { lockdown patients. }\end{array}$ & $\begin{array}{l}\text { The C19PRC made it possible to } \\
\text { contribute to understanding mental health } \\
\text { in patients who have suffered severe } \\
\text { respiratory symptoms caused by COVID- } \\
19 \text { for research and public health } \\
\text { communities in the United Kingdom. }\end{array}$ \\
\hline
\end{tabular}

* Black, Asian, and minority ethnic - a term used by the English people in their studies. Source: Authors 


\section{Discussion}

Studies produced in the United States of America (3), England (3), multicenter studies (4), Spain (1) and Mexico (1) were found.

The studies were organized according to the main object of each one. Thus, three categories of analysis emerged: 1 Racial inequality and the way black immigrants face the COVID-19 pandemic; 2- Access to healthcare for black immigrants during the COVID-19 pandemic; 3- The influence of COVID-19 on the mental health of black immigrants, which are presented in Table 2.

It is noteworthy that although the studies have been categorized to better organize the presentation of results, all categories are unified concerning the determinants of living conditions in racial and social aspects of health.

Table 2 - Articles selected according to the corresponding analysis categories.

\begin{tabular}{|c|c|c|}
\hline Empirical Categories & Topics covered & Study reference according Table 1 \\
\hline \multirow[t]{3}{*}{$\begin{array}{l}1 \text { - Racial inequality and how black } \\
\text { immigrants face the COVID-19 } \\
\text { pandemic }\end{array}$} & $\begin{array}{l}\text { 1.1 Black population (immigrant or not) } \\
\text { is the most affected by COVID-19 }\end{array}$ & $1,2,3,4,5$ \\
\hline & 1.2. Economic impact & $2,4,5$ \\
\hline & 1.3. Lockdown Impact & 6 \\
\hline \multirow{3}{*}{$\begin{array}{l}2 \text { - Access to healthcare for black } \\
\text { immigrants during the COVID-19 } \\
\text { pandemic }\end{array}$} & $\begin{array}{l}\text { 2.1 Need for access to reproductive and } \\
\text { sexual health }\end{array}$ & 7,8 \\
\hline & 2.2 Living in unhealthy conditions & 11 \\
\hline & $\begin{array}{l}2.3 \text { Income deprivation impedes access } \\
\text { to health }\end{array}$ & $10,11,12$ \\
\hline $\begin{array}{l}3 \text { - The influence of COVID-19 on the } \\
\text { mental health of black immigrants }\end{array}$ & $\begin{array}{l}3.1 \text { Isolation and lockdown measures } \\
\text { affect mental health }\end{array}$ & 13 \\
\hline
\end{tabular}

\section{Source: Authors.}

The materials that made up the category Racial inequality and the way black immigrants face the COVID-19 pandemic presented the characteristics of an original reflection article (2), a letter to the editor (1), an editorial (1) and an article by a literature review (1). All presented objectives that sought to analyze the relationship between the COVID-19 pandemic and the living conditions of a population labeled as a minority, except for the review study that pointed out an article in its results debating the racial relationship (Glover, et al., 2020).

The analysis of racial inequalities and social inequalities that the pandemic showed, can be seen as an expression of the intrinsic relationship of these two phenomena Racism and COVID-19. No material analyzed in this review dealt exclusively with the black immigrant population, showing the need for further studies to investigate more accurately or how 
Research, Society and Development, v. 11, n. 1, e2511124073, 2021

(CC BY 4.0) | ISSN 2525-3409 | DOI: http://dx.doi.org/10.33448/rsd-v11i1.24073

the COVID-19 pandemic is expressed in this population group.

Three studies 1, 2, 3 sought to bring the analysis of racial inequalities, with the black population suffering the most with both the number of cases and deaths by COVID-19 and the social inequalities in comparison with other populations, whether they are immigrants or not. A study13 from the United States of America aimed to debate how the economy of black, immigrant and non-white people, with the coming of the economic crisis that COVID-19 triggered, had a direct impact on the mental health of these people.

The study 4, organized data from 13 countries, analyzing the social condition and drawing the parallel with the high rates of the impact of cases and lethality of the disease in the black population, in several countries, these people developed more severe cases in need of hospitalization and more likely to die.

The article 5, pointed out that the population labeled as BAME suffers the most from the impacts generated by the lockdown, especially regarding their mental health, due to restricted access to basic services and working conditions.

The second category, Access to healthcare for black immigrants during the COVID-19 pandemic, presented original articles with a quantitative approach and an original reflection article, which discussed access to basic living conditions and how the socioeconomic situation influenced individuals with COVID-19, characterizing the reality of the immigrant population in the places where the studies were carried out.

One of the studies, 7 , indicates the need to debate the access of immigrants to reproductive and sexual health services during the pandemic. In the United States of America, immigrants do not have access to private health services, there is, therefore, an exclusion from health services for this population, exacerbated by the fact that they stay illegally in the country, as is the case for many immigrants. As an alternative, the article proposes the creation of policies that address health as a right of immigrants and that these inhabitants are recognized as participants in the population.

The research 8, identified that immigrants from sub-Saharan Africa who live in Spain had high mortality rates for COVID-19, followed by Afro-Caribbean and Latino immigrants. These data were attributed to the lack of access to health services experienced by the populations investigated.

The survey carried out in Mexico, 9, points out that there is little data on how the immigrant population is affected by COVID-19. The population studied was that of immigrants who live in border cities, with many living in shelters and unhealthy conditions. The majority of the population studied that needed health services and intubation were the immigrant populations, pointing out that social issues have a high impact on the lives of the immigrant population, who normally leave their countries of origin in search of better living conditions and end up facing situations of vulnerability.

Studies carried out with data from England 10,11,12 sought to identify socioeconomic factors and the relationship between mortality rates among the population labeled as BAME. They brought evidence that income deprivation is directly associated with higher mortality from COVID-19, as well as lack of access to public services, which also negatively influences the mental health of the population.

The third category, The influence of COVID-19 on the mental health of black immigrants, consisted of a multicenter study, number 13. The study sought to identify possible psychological changes using the C19PRC-UKW1 questionnaire, which points out domains of socioeconomic identification, characteristics of comorbidities, and psychological nature, being applied to individuals during social isolation as a measure to contain the spread of the virus that causes COVID- 19 .

The study number 13 pointed out that effective public policies aimed at improving the population's quality of life should be generated, as the data showed psychological and behavioral changes during the pandemic with measures of social isolation and lockdown. It also highlighted the relationship between the pandemic and the increase in the number of situations 
of domestic violence during the period of isolation and that measures that seek a solution to this public health problem in the short and long term must be taken.

The results of this study indicate that the use of the term minorities, adopted by many of the materials that made up the corpus of analysis of this review, is often used to label individuals in the same classification, but it ends up being negligent and excluding when trying to fit into the same denomination various subgroups from different contexts, such as women, blacks, poor, religious groups, and immigrants. Thus, the question arises: what is the real meaning of this name? Would it be a minority in the quantitative sense, or does it indicate discrimination or fewer chances of accessing power? The creation of a term that tries to cover countless individuals, placing them in a debate position before the State of the Nation does not do justice to the individual reality of any population (VIANA, 2016).

The study 13 pointed out that effective public policies aimed at improving the population's quality of life should be generated, as the data showed psychological and behavioral changes during the pandemic with measures of social isolation and lockdown. It also highlighted the relationship between the pandemic and the increase in the number of situations of domestic violence during the period of isolation and that measures that seek a solution to this public health problem in the short and long term must be taken.

Therefore, in this research, the term minorities were not used to identify the populations studied, but rather its identification characteristic. When the subject is highlighted, the possibility of changing the reality to be transformed arises. This research sought to identify the health situation of black immigrants during the COVID-19 pandemic. However, none of the analyzed materials spoke about a specific group of immigrants, all documents that made up the sample grouped immigrants with other individuals, grouping them in the same class: that of minorities (SANTOS, 2018).

Discrimination against immigrants, whether in terms of spaces, access to health systems, or access to minimum living conditions, can be understood as one of the expressions of neo-fascist thinking. The idea of granting rights to life by the nationstate, linked to allowing access only to those who are born in its territory, that is, only to those who are wrongly considered equals, retains the thought of nationalist origin (HAESBAERT, 2019). This exclusion of individuals translates the idea of denying what comes from outside, which is enhanced when outside individuals are recognized as black.

Despite the creation of an effective vaccine against COVID-19, it is understood that the crisis caused by the COVID19 pandemic will still produce consequences that will widen the inequalities in access to health among people. Its global confrontation depends on the development of actions that promote the control of the spread of the virus globally and in a sustainable way. Countries must act in the creation of public policies and health care based on social participation and control28, such as, for example, the minimum income policy and guarantee of access to public services for all.

Overcoming the racist power structure comes primarily from its recognition, together with practices of forms of sociability and dialogue of social antagonisms in search of understanding and the construction of anti-racist practices for overcoming and social transformation (ALMEIDA, 2017).

The limitation of this study is due to the non-use of descriptors or keywords related to the black population. It is justified that this limitation did not affect the tracking of documents that made up the sample, as the materials that dealt with the black population were selected by reading the texts in full.

\section{Conclusion}

The results of this study indicate that publications about the health situation of black immigrants during the COVID19 pandemic deal with issues related to race, access to health and living conditions, and mental health. Although they are 
Research, Society and Development, v. 11, n. 1, e2511124073, 2021

(CC BY 4.0) | ISSN 2525-3409 | DOI: http://dx.doi.org/10.33448/rsd-v11i1.24073

presented in an isolated way for analysis, it is understood that these issues are intertwined insofar as they express conditions relating to the social determinants of health of the black immigrant population.

In addition, the data show how the black population, in general, was the most affected in the world by COVID-19 and bring scientific evidence about the presence of structural racism as a determining power structure in the contamination and aggravation of COVID-19 in these individuals. Due to the deterritorialization to which the black population was subjected during its history, these bodies continue to be discriminated against and excluded, as can be seen from the absence of these populations in official reports that allow tracking of the number of infected, dead, and recovered from COVID-19. In addition to the absence of official statistics, black immigrants add to the condition of illegality to which many are conditioned. There is a need for future researchers about the subject-matter.

It is imperative to create spaces for dialogue by the scientific, academic, and civil communities, to promote the recognition of racism as structuring of behavior and determinants in the life of the black immigrant population and the construction of anti-racist policies that walk in a logic of reparation history with this population.

\section{References}

Aldridge, R. W., et al. (2020). Black, Asian and Minority Ethnic groups in England are at increased risk of death from COVID-19: indirect standardisation of NHS mortality data. Wellcome Open Research, 5 (88). doi: 10.12688/wellcomeopenres.15922.2

Almeida, S. (2019). Racismo estrutural. Pólen Produção Editorial LTDA.

Almeida, S. (2020). Capitalismo e Crise: O que o racismo tem a ver com isso? https://blogdaboitempo.com.br/2020/06/23/capitalismo-e-crise-o-que-oracismo-tem-a-ver-com-isso/

Bojorquez, I., et al. (2020). Migrants in transit and asylum seekers in Mexico: an epidemiological analysis of the covid-19 pandemic. medRxiv. doi: 10.1101/2020.05.08.20095604

Desai, S. \& Samari, G. (2020). COVID-19 and Immigrants' Access to Sexual and Reproductive Health Services in the United States. Perspectives on Sexual and Reproductive Health, 52(2), 69-73. doi: 10.1363/psrh.12150

Glover, R. E., et al. (2020). A framework for identifying and mitigating the equity harms of COVID-19 policy interventions. Journal of Clinical Epidemiology, 128, 35-48.doi: 10.1016/j.jclinepi.2020.06.004

Goes, E. F., et al. (2020). Racial health inequalities and the COVID-19 pandemic. Trabalho, Educação e Saúde, 18(3),1-7.doi: 10.1590/1981-7746-sol00278

Guijarro, C., et al. (2020). Risk for COVID-19 among Migrants from different areas of the world in Spain: A population-based cohort study in a country with universal health coverage. medRxiv. doi: 10.1016/j.rce.2020.10.006

King, D. (2020). The Independent SAGE Report. COVID-19: what are the options for the UK? https://www.independentsage.org/wpcontent/uploads/2020/05/The-Independent-SAGE-Report.pdf

Kapilashrami, A. \& Bhui, K. (2020). Mental health and COVID-19: is the virus racist?. The British Journal of Psychiatry, 217(2),405-407. doi: $0.1192 /$ bjp. 2020.93

Krouse, H. J. (2020). COVID-19 and the Widening Gap in Health Inequity. Otolaryngology-Head and Neck Surgery, 163(1),65-66. doi: $10.1177 / 0194599820926463$

Lassale, C., et al. (2020). Ethnic Disparities in Hospitalisation for COVID-19 in England: the role of socioeconomic factors, mental health, and inflammatory and pro-inflammatory factors in a community-based cohort study. Brain, Behavior, and Immunity, 88, 44-49. doi: 10.1016/j.bbi.2020.05.074

McBride, O., et al. (2021). Monitoring the psychological, social, and economic impact of the COVID-19 pandemic in the population: Context, design and conduct of the longitudinal COVID-19 psychological research consortium (C19PRC) study. International journal of methods in psychiatric research, 30(1), e1861. https://doi.org/10.1002/mpr.1861

Peters, M. D. J. et al. (2017) Chapter 11: Scoping Reviews. In: Aromataris E, Munn Z (Editors). Joanna Briggs Institute Reviewer's Manual The Joanna Briggs Institute. https://jbi-global-wiki.refined.site/space/MANUAL/3283910770/Chapter+11\%3A+Scoping+reviews

Prado, M., et al. (2020). Análise da subnotificação de COVID-19 no Brasil. Rev. bras. ter. Intensive, 32 (2), 224-228. doi: 10.5935/0103-507X.20200030

Razaq, Abdul, et al. (2021) BAME Covid-19 Deaths - what do we know?: rapid data \& evidence review. Oxford COVID-19 Evidence Service. https://www.cebm.net/covid-19/bame-covid-19-deaths-what-do-we-know-rapid-data-evidence-review/

Rose, T.C., et al. (2020). Inequalities in COVID19 mortality related to ethnicity and socioeconomic deprivation. MedRxiv. 
Research, Society and Development, v. 11, n. 1, e2511124073, 2021

(CC BY 4.0) | ISSN 2525-3409 | DOI: http://dx.doi.org/10.33448/rsd-v11i1.24073

doi: $10.1101 / 2020.04 .25 .20079491$

Santos, G. A. (2018). Raça e Gênero: contribuições para pesquisas nas ciências sociais e jurídicas. Interfaces Brasil/Canadá, $18(3), 42-77$.

Shadmi, E., et al. (2020). Health equity and COVID-19: global perspectives. International journal for equity in health, 19 (104),1-16. doi: 10.1186/s12939020-01218-Z

Souza, A. N. (2019). Os territórios simbólicos no processo de territorialização e desterritorialização cultural, na perspectiva de Rogério Haesbaert. JAMAXI, $3(2), 1-8$.

The COVID Tracking Project. (2021). The COVID Racial Data Tracker. The Atlantic. https://covidtracking.com/race

The Joanna Briggs Institute. (2015). Joanna Briggs Institute reviewers' manual: 2015 edition/supplement. Adelaide: The Joanna Briggs Institute. https://wiki.joannabriggs.org/display/MANUAL/Chapter+11\%3A+Scoping+reviews

Treweek, S., et al. (2020). COVID-19 and ethnicity: who will research results apply to?. The Lancet, 395(10242),1955-1957. doi: 10.1016/S0140$6736(20) 31380-5$

Tricco, A.C., et al. (2016). A scoping review on the conduct and reporting of scoping reviews. BMC Med Res Methodol, 16(15), 2-10. doi: 0.1186/s12874016-0116-4

Tricco, A.C., et al. (2018). PRISMA Extension for Scoping Reviews (PRISMA-ScR): checklist and Explanation. Ann InternMed, 169(7), 67-73. doi: 10.7326/M18-0850

Viana, N. (2016). O Que São Minorias?. Revista Posição 3(9), 27-32.

Watson, M. F, et al. (2020). COVID-19 Interconnectedness: Health Inequity, the Climate Crisis, and Collective Trauma. Family process, 59(3), 832-846. doi: 10.1111/famp.12572

World Health Organization. (2021). Coronavirus (COVID-19) Dashboard.

https://covid19.who.int/?gclid=Cj0KCQjwpZT5BRCdARIsAGEX0zkX89ZU_mamGd7Qk9UsxRtlZFCJ6K3dZfeSA1wDoOJQJVgyVYbWZ9EaAv7NEALw -wcB 